\title{
Effect of Flooding Frequency and Nutrient Addition on Plant Growth and Total Petroleum Hydrocarbons Removal in Mangrove Microcosms
}

\author{
María E. Hernández ${ }^{1}$ José L. Marín-Muñiz², Eugenia J. Olguín1 \\ ${ }^{1}$ Biotechnological Management of Natural Resources Network, Institute of Ecology, Veracruz, Mexico \\ ${ }^{2}$ Chemical and Environmental Engineering School, University of Veracruz, Veracruz, Mexico \\ Email: elizabeth.hernandez@inecol.mx, soydrew@hotmail.com, eugenia.olguin@inecol.mx
}

Received 27 September 2014; revised 28 October 2014; accepted 16 November 2014

Copyright (C) 2014 by authors and Scientific Research Publishing Inc.

This work is licensed under the Creative Commons Attribution International License (CC BY). http://creativecommons.org/licenses/by/4.0/

(c) (i) Open Access

\section{Abstract}

The addition of nutrients to accelerate biodegradation of oil is an adequate strategy to clean up polluted mangrove soils which pollutes mangrove soils. However, the hydrology of these ecosystems might interfere with such strategy. The effect of flooding frequency and nutrient addition on hydrocarbon removal in mangrove sediments was investigated in this study. Microcosms consisted of pots with $5 \mathrm{~kg}$ of fresh mangrove sediments and one seedling of Avicennia germinans. Treatments included: planted microcosms with fertilizer and crude oil (PNC), planted microcosms with oil (PC), non-planted microcosms with oil and fertilizer (NC), planted microcosms with fertilizer (PN) and planted microcosms without oil or fertilizer (P). Mexican Maya crude oil and inorganic nutrients were added in a single dose of approximately $5.0 \mathrm{~g} \mathrm{DW} \cdot \mathrm{kg}^{-1}, 0.33 \mathrm{~g} \mathrm{of} \mathrm{N} \mathrm{DW} \cdot \mathrm{kg}^{-1}$ and $0.06 \mathrm{~g} \mathrm{P} \mathrm{DW} \cdot \mathrm{kg}^{-1}$. Microcosms were either permanently flooded (PF) or intermittently flooded (IF: 14 hours drained and 10 hours flooded), and kept in a glasshouse in Xalapa, Veracruz, Mexico. In both flooding conditions, oil decreased the relative growth rate of $A$. germinans by $56 \%$ in (PC) treatments and $40 \%$ in (PNC) treatments. Redox potential in the oiled treatments $(-44.73$ to +75.34 $\mathrm{mV}$ ) was lower than non-oiled treatments $(-1.31$ to $+163.43 \mathrm{mV})$. Total Petroleum Hydrocarbons (TPHs) removal in PC treatments was low in both permanent $(2.99 \% \pm 3.51 \%)$ and intermittently flooding conditions $(11.75 \% \pm 1.46 \%)$. The highest TPHs removal was observed in (PNC) and (NC) under IF conditions $(47 \% \pm 3.86 \%$ and $50.32 \% \pm 7.15 \%$ after 4 months, respectively). It was concluded that nutrient addition increased TPHs removal but only under IF conditions and helped mangrove plants to deal with TPHs toxicity. 


\section{Keywords}

\section{Avicennia germinans, Hydrocarbons, Biostimulation, Oxygen Availability}

\section{Introduction}

Mangrove forests are ecotones between marine and terrestrial ecosystems, commonly found along low wave energy shorelines in tropical and subtropical regions [1]. Mangrove ecosystems provide important environmental services including the stabilization and maintenance of various adjoining ecosystems; they are also habitats for juvenile crustaceans and other species [2]. Unfortunately, mangrove ecosystems are one of the most potentially vulnerable of the intertidal communities to oil pollution [3] [4]. In the last 30 years, several oil spill accidents have occurred in marine systems affecting mangrove habitats around the world [5]-[9]. The mortality and damages due to oil contamination in mangroves depend on the type, quantity and weathered state of the oil, the mangrove species, and the prevailing climatic and tidal conditions [3] [4] [10]. In Mexico, oil extraction and refining is performed mainly in the coastal states of Veracruz, Tabasco and Campeche, in the southern part of the Gulf of Mexico, where mangrove ecosystems are abundant [11] [12]. Recurrent oil spills in these areas have polluted Mexican mangrove ecosystems [13] [14]. Protocols utilized for oil clean up involve the use of dispersants, cleaners, and soil oxidizers as well as mechanical techniques that involve collection and skimming, cutting and removal of contaminated vegetation, and gentle flushing with clean water. However, oil collection and skimming may greatly damage plants [15]. Bioremediation is an ecological alternative for detoxification of oiled mangrove sediments which is highly efficient for the removal of hydrocarbons even at low concentrations [16][18]. However, oil bioremediation in Mexican mangrove soils has received little attention [16]. Mangrove restoration after oil spills should involve the cleanup of oil from the soils before reforestation. There are two strategies for oil bioremediation in soils: bioaugmentation, which involves the addition of external (indigenous or exogenous) microbial populations to contaminated soil and biostimulation, which involves the addition of appropriate microbial nutrients to a polluted soil or water to stimulate biodegradation of pollutants by endogenous microorganism [19].

Field and laboratory studies with mangrove slurries and salt marsh sediments have concluded that bioaugmentation for hydrocarbon bioremediation in wetlands soil is not necessary, because these soils are rich in native microorganisms that are able to degrade hydrocarbons [20]-[22]. On the other hand, biostimulation has demonstrated the ability to accelerate oil biodegradation, because some coastal wetland soils are poor in nutrients [23][25]. From the review of various reports dealing with bioremediation of oil-polluted mangrove's ecosystems, it was concluded that biostimulation with fertilizers and aeration by low cost-practices such as soil farming, were the most appropriate strategies for achieving significant hydrocarbon removal [16].

Hydrology in mangrove ecosystems is dynamic and the degree and frequency of inundation depend on microtopography and tidal height, showing spatial and seasonal variations [26]. Nutrient biogeochemistry and hydrocarbon degradation in wetland soils is influenced by oxygen availability; biodegradation of hydrocarbons is faster under aerobic conditions than anaerobic or anoxic conditions [27]. Redox potential measurements in wetland soils allow rapid determination of the degree of reduction (anaerobiosis) or oxidation (aerobiosis). This parameter is strongly influenced by wetland hydrology [1] [28]. Currently, little is known about the influence of flooding frequency on nutrient addition for accelerating oil removal in mangrove ecosystems.

The objective of this study is to investigate the effect of flooding frequency and nutrient addition on plant growth, redox potential, and TPHs removal in mangrove microcosms. The hypothesis was that nutrient addition and intermittent flooding conditions will increase TPHs removal.

\section{Material and Methods}

\subsection{Mangrove Microcosms and Experimental Design}

A total of 40 mangrove microcosms were used in the experiment. Each microcosm consisted of a plastic pot ( $0.20 \mathrm{~m}$ in diameter and $0.20 \mathrm{~m}$ in height), filled with $5 \mathrm{~kg}$ of fresh mangrove sediment and planted with one healthy young seedling of black mangrove (Avicennia germinans, $0.26 \pm 0.05 \mathrm{~m}$ average initial height). Man- 
grove seedlings were obtained from a Mexican National Forestry Commission nursery, located in Alvarado, Veracruz. Seedlings were watered with fresh water and kept in a glasshouse in Xalapa, Veracruz $\left(19^{\circ} 32^{\prime} 31^{\prime \prime} \mathrm{N}\right.$ and $95^{\circ} 54^{\prime} 35^{\prime \prime} \mathrm{W}$ ), for six months before they were planted in the experimental microcosms. Mangrove sediments used in the microcosms were collected in an oil free site in La Mancha lagoon, located on the coast of Veracruz State in the southern Gulf of Mexico $\left(19^{\circ} 34^{\prime} \mathrm{N}, 19^{\circ} 42^{\prime} \mathrm{N}\right.$ and $96^{\circ} 23^{\prime} \mathrm{W}$ y $\left.96^{\circ} 27^{\prime} \mathrm{W}\right)$. Physicochemical characteristics of mangrove soils are shown in Table 1. Microcosms were divided in two groups: 20 were permanently flooded (PF) and 20 were intermittently flooded (IF). Each group contained five treatments of four replicates. Treatments consisted of planted microcosms with nutrients and crude oil (PNC), planted microcosms with crude oil (PC), unplanted microcosms with crude oil and nutrients (NC), planted microcosms with nutrients (PN) and planted microcosms without oil or nutrients (P).

\subsection{Hydrology}

Seventy liters $(70 \mathrm{~L})$ plastic bins $(0.60 \mathrm{~m}$ diameter $\times 0.35 \mathrm{~m}$ height) were used for flooding the microcosms. A total of 10 bins were used, one for each treatment, each bin had four microcosm replicates. The bins were individually plumbed to have a constant recycling water flow. Water was pumped with a fountain pump (Beckett, M130AUL16) from a $70 \mathrm{~L}$ plastic container to each bin. For permanently flooded conditions, water entered at one side of the bin ( $0.26 \mathrm{~m}$ height) by a $0.012 \mathrm{~m}$ internal diameter hose, and water exited the bin in the opposite corner at the same height, flowing back by gravity to a $70 \mathrm{~L}$ plastic container. For intermittently flooding conditions, bins had flooding cycles that consisted of draining for 14 hours (19:00 to 9:00 hours) followed by 10 hours of flooding (9:00 to 19:00 hours). To achieve intermittent flooding, the tanks had an extra outlet consisting of $0.012 \mathrm{~m}$ internal diameter hose in the bottom, attached to a valve that drained by gravity to the water container. When the tanks were flooded, the valve was closed and when the tanks were drained the valve was open, in both cases water was constantly recycling between the bin and the container. Mangrove microcosms were planted and watered with fresh water for 30 days to enhance the establishment of vegetation. Thereafter, they were permanent or intermittently flooded with fresh water, for one week and later with artificial seawater (Instant Ocean, Aquarium Systems, Inc., Mentor $\mathrm{OH}$ ); salinity was maintained at 5\% for the first week, at 10\% for the second week and 15\%o for 65 days before the addition of oil and nutrients.

\subsection{Oil and Nutrient Addition}

Mexican Maya crude oil from the Gulf of Mexico, characterized by low viscosity with a specific gravity of 0.8 $\mathrm{g} \cdot \mathrm{L}^{-1}$ and inorganic nutrients (Nitrofosca) in the form of $\mathrm{NH}_{4} \mathrm{NO}_{3}$ and $\mathrm{K}_{2} \mathrm{HPO}_{4}$ were used in the experiment. Oil was added in a single dose of $5.0 \mathrm{~g} \cdot \mathrm{Kg}^{-1}$ of DW sediment (equivalent to $0.8 \mathrm{~L} \cdot \mathrm{m}^{-2}$ ), by pouring the liquid

\begin{tabular}{|c|c|}
\hline Parameter & Value \\
\hline Sand (\%) & $79.73 \pm 1.46$ \\
\hline Silt (\%) & $13.42 \pm 0.37$ \\
\hline Clay (\%) & $6.85 \pm 1.83$ \\
\hline Moisture (\%) & $37.00 \pm 0.73$ \\
\hline $\mathrm{pH}$ & $7.89 \pm 0.09$ \\
\hline $\mathrm{P}-\mathrm{PO}_{4}\left(\mathrm{mg} \cdot \mathrm{kg}^{-1} \mathrm{dw}\right)$ & $14.68 \pm 1.04$ \\
\hline $\mathrm{N}-\mathrm{NO}_{3}\left(\mathrm{mg} \cdot \mathrm{kg}^{-1} \mathrm{dw}\right)$ & $24.73 \pm 0.26$ \\
\hline $\mathrm{N}-\mathrm{NH}_{4}\left(\mathrm{mg} \cdot \mathrm{kg}^{-1} \mathrm{dw}\right)$ & $5.77 \pm 0.19$ \\
\hline Bulk density $\left(\mathrm{g} \cdot \mathrm{cm}^{-3}\right)$ & $1.26 \pm 0.01$ \\
\hline Organic matter (\%) & $4.70 \pm 0.13$ \\
\hline
\end{tabular}

Values are average \pm standard error. 
uniformly over the sediment surface and rinsing the used cylinder glass with warm $\left(37^{\circ} \mathrm{C}\right)$ water. Before oil addition, all microcosms were drained for 48 hours and remained drained for another 48 hours after oil addition, to allow oil adsorption to the sediments. Nutrients were subsequently added to the microcosms in a concentration of $0.3322 \mathrm{~g} \mathrm{~N} \mathrm{Kg}^{-1} \mathrm{DW}$ of sediment equivalent to $42.3 \mathrm{~g} \mathrm{~N} \mathrm{~m}^{-2}$ and $0.0664 \mathrm{~g} \mathrm{P} \mathrm{Kg}^{-1} \mathrm{DW}$ of sediment' equivalent to $8.46 \mathrm{~g} \mathrm{P} \mathrm{m}^{-2}$. One concern of biostimulation in coastal ecosystems is the rapid loss of the fertilizer by washout, resulting in nutrient enrichment of coastal waters. In order to prevent this phenomenon, a gradual release of the nutrients is needed. Sato et al. [29], described a simple method to fertilize mangroves trees in Asia, which consisted of placing the fertilizer in perforated plastic bags. In this study we used a similar method to add the nutrients for biostimulation. Fertilizer was placed in two small $(0.02 \times 0.02 \mathrm{~m})$ polyethylene bags with four holes punched in each corner with a push pin. Each bag was attached with a string to a $0.25 \mathrm{~m}$ long wooden stick, and buried $0.07 \mathrm{~m}$ into the sediment. Nutrient bags were placed $0.14 \mathrm{~m}$ apart in each pot. The sticks served as a reference to avoid withdrawing the fertilizer bags during sediment sampling. After fertilizer addition, the microcosms were re-flooded with new artificial seawater (salinity 15\%o), and maintained at a consistent water level (0.04 $\mathrm{m}$ above sediment surface during the four months of hydrocarbon removal experiment). Water levels in the water containers were measured every three days, and water lost by evapotranspiration was replaced.

\subsection{Plant Growth}

The initial leaf, branch and node number, basal diameter, and height of each individual mangrove seedling were measured during planting the microcosms. During planting, five random plant samples were harvested and their leaf number, branch and node number, basal diameter, and height were recorded. These plants were rinsed and separated into roots and areal biomass (steam and leaves), and dried at $40^{\circ} \mathrm{C}$ to a constant weight within $0.001 \mathrm{~g}$ accuracy. At the end of the experiment, all plants were harvested and separated individually into roots, stems and leaves; they were then washed and dried to a constant weight at $40^{\circ} \mathrm{C}$.

Relative growth rates (RGR) were calculated as described by Youssef [10] according to Equation (1).

$$
R G R=\ln W 2-\ln w 1 /(t 2-t 1)
$$

where: $R G R$ is the relative growth rate (g DW g ${ }^{-1} \mathrm{~d}^{-1}$ ), $W 1$ and $W 2$ are the dry weight (g) of total biomass (below ground + above ground) when mangrove microcosms were planted $(t 1)$, and at end of the experimental period $(t 2)$.

\subsection{Environmental Conditions Monitoring}

Light intensity and temperature were recorded three times per day (10:00, 14:00 and 17:00 h) inside the greenhouse using a light meter (Exteh Mod 401025) and a generic wall thermometer. During the experimental period (from April to August), average light intensities were $121.73 \pm 1.22 \mu \mathrm{mol} \cdot \mathrm{m}^{-2} \mathrm{~s}^{-1}$ at 10:00 am, $171.72 \pm 1.53$ $\mu \mathrm{mol} \cdot \mathrm{m}^{-2} \mathrm{~s}^{-1}$ at $2: 00 \mathrm{pm}$ and $38.5 \pm 0.55 \mu \mathrm{mol} \cdot \mathrm{m}^{-2} \mathrm{~s}^{-1}$ at 5:00 $\mathrm{pm}$. Average temperatures were $26.5^{\circ} \mathrm{C} \pm 0.1^{\circ} \mathrm{C}$, at 10:00 am, $30.8^{\circ} \mathrm{C} \pm 0.1^{\circ} \mathrm{C}$ at $2: 00 \mathrm{pm}$ and $24.7^{\circ} \mathrm{C} \pm 0.1^{\circ} \mathrm{C}$ at $\left.5: 00 \mathrm{pm}\right)$.

\subsection{Redox Potential Measurements}

Soil redox potential (Eh) was measured at 7 and $14 \mathrm{~cm}$ depths using platinum electrode, one calomel reference electrode (Corning 476340) and a digital multimeter (Master MAS830B). Platinum electrodes were calibrated before measurements with $0.005 \%$ quinhydrone (Sigma Q-1001) in pH 4.0 buffer solution [30]. To calculate Eh, $244 \mathrm{mV}$ was added to each $\mathrm{mV}$ reading as a correction factor due to the potential of calomel reference electrode. In order to avoid oil film interferences with the redox potential measurement, both reference electrode and platinum rods were rinsed with water:ethanol solution 1:1 (v/v) after every reading.

\subsection{Nutrient Analysis in Sediment and Water}

Water samples were taken at the beginning of the biodegradation experiment, four hours after re-flooding the microcosms and every 20 days for four months. These water samples $(100 \mathrm{ml})$ were taken from each tank and $\mathrm{N}-\mathrm{NH}_{4}^{+}, \mathrm{N}-\mathrm{NO}_{3}^{-}$and $\mathrm{P}-\mathrm{PO}_{4}^{3-}$ concentration was analyzed. Sediments were sampled before fertilizer addition, after re-flooding, then every 40 days for 4 months. For nutrient analysis, one sediment core $(0.025 \mathrm{~m}$ diameter by $0.14 \mathrm{~m}$ height) was taken from each microcosm. Each core was homogenized and placed in a plastic bag, and 
kept at $4{ }^{\circ} \mathrm{C}$ until analysis (no more than two weeks). $\mathrm{N}_{-} \mathrm{NH}_{4}^{+}$and $\mathrm{N}-\mathrm{NO}_{3}^{-}$were extracted from $10 \mathrm{~g}$ of fresh sediment with $50 \mathrm{ml} \mathrm{KCl} 2 \mathrm{M}$ solution at $180 \mathrm{rpm}$ for one hour [31]. Nitrates and ammonia in the extract were quantified according to Robarge et al. [32]. Phosphates were extracted from $10 \mathrm{~g}$ of fresh sediments with $50 \mathrm{ml}$ of a solution of $\mathrm{NH}_{4} \mathrm{~F} 0.03 \mathrm{~N}+\mathrm{HCl} 0.1 \mathrm{~N}$ over one hour. Phosphates were quantified using the ascorbic acid method according to Sandell and Onish [33].

\subsection{Total Petroleum Hydrocarbons (TPHs) in Water and Sediments}

TPHs were analyzed in water and sediments after oil and fertilizer addition and after 120 days of experimental conditions. Two sediment cores ( $0.025 \mathrm{~m}$ diameter by $0.14 \mathrm{~m}$ height) were taken in each microcosm, homogenized and placed in aluminum foil pans, then frozen at $-10^{\circ} \mathrm{C}$ until analysis. Water samples $(0.5 \mathrm{~L})$ for hydrocarbon analysis were taken after oil and fertilizer addition, and after 120 days, before scraping the tanks and hoses and after scraping oil from the hoses and the tank walls.

TPHs were extracted with solvent mixture of acetone-hexane $(1: 1 \mathrm{v} / \mathrm{v})$ and quantified by measuring the absorbance at $400 \mathrm{~nm}$ [20]. Briefly, $2 \mathrm{~g}$ of fresh sediment was extracted with $0.07 \mathrm{~L}$ of acetone-hexane solvent for 1 hour using an ultrasonic bath at $20^{\circ} \mathrm{C}$, the extraction was repeated twice, the extracts were mixed and their absorbance at $400 \mathrm{~nm}$ were measured in a spectrophotometer (Hach Model 6100).

TPHs in water were quantified by extraction of $0.2 \mathrm{~L}$ of water with $0.06 \mathrm{~L}$ of acetone-hexane $(1: 1 \mathrm{v} / \mathrm{v}) \mathrm{in}$ a separation funnel. The organic layer was separated and filtered through glass wool with $0.2 \mathrm{~g}$ of anhydrous sulfate. The extraction was carried out twice; filtered organic layers were mixed and the absorbance was measured at $400 \mathrm{~nm}$.

\subsection{Compartmentalization of THPs in the System}

In order to investigate if the hydrocarbons migrated from soil to water or to the walls of the plastics bins and tank used to flood the system, the amount of hydrocarbon in the different matrixes (water, sediments and the walls of plastic bins, tanks and hoses) was calculated. At the end of the experiment, the TPHs adhered to the walls of the different parts (plastic bins, pots, tanks and hoses) were scraped with a metallic spatula and emulsified with a known amount of water. TPHs in this emulsion were quantified as described before. The total amount of crude oil added to the four microcosm of each treatment and the total amount of water used to flood them $(60 \mathrm{~L})$ were considered. Due to the fact that each treatment had four replicates but they were flooded in the same bin and share the same water container only one value of TPHs for each treatment was generated for each of the three matrices. TPHs lost by volatilization were measured according to Wright et al. [34]. A known weight of crude oil was placed in a plastic bin (bin $(4 \mathrm{~cm}$ high $\times 10 \mathrm{~cm}$ diameter) next to the experimental units and its weight was monitored every week. The amount of TPHs removed from the system was calculated according with the Equation (2):

$$
T P H s R=100-T P H s W T 120-T P H s S T 120-T P H s W L L T 120+T P H s V
$$

where: $T P H s R=\%$ of TPHs removed from system, TPHsWT120 $=\%$ of initial amount of TPHs in water at day 120, TPHsST120 $=\%$ of initial amount of TPHs in sediment at day 120, TPHsWLL120 $=\%$ of initial amount of TPHs in walls at day 120 and $T P H s V=\%$ of initial amount of TPHs lost by volatilization.

\subsection{Statistical Analysis}

Statistical analyses were performed with SPSS version 14 for Windows. Kolmogrov-Smirnov, Lilliefors' and Shapiro-Wilk's tests were used to check normality. The data fit normal distributions. Two-way analysis of variance (ANOVA) with Tukey HSD multiple comparison tests were used to investigate the effect of flooding frequency and treatment on plant growth, redox potential and oil degradation. When variance was not homogeneous, Games-Howell multiple comparison tests were used. A 5\% significance level was used to determine differences among treatments.

\section{Results}

\subsection{Plant Growth}

Flooding frequency did not have a significant effect on aerial or underground biomass production of A. germi- 
nans (Figure 1). However, there was a significant effect $(p=0.001)$ of treatments, i.e. oil and nutrient addition, and a combined effect of flooding frequency and treatment $(p=0.012)$ on aerial biomass production. Oil presence in the microcosms (PC, PNC) caused significantly lower aerial biomass production (PC $=6.77 \mathrm{~g}$ and $6.93 \mathrm{~g}$ under IF, PNC = $11.87 \mathrm{~g}$ and $10.15 \mathrm{~g}$, respectively under $\mathrm{PF})$, than fertilized treatments without oil $(\mathrm{PN}=19.51$ $\mathrm{g}$ and $14.59 \mathrm{~g}$ under IF and PF conditions, respectively). However, aerial biomass production in oiled microcosms (PC, PNC) was not significantly different from the non-fertilized control microcosms P (8.24 g and 12.28 g under IF and PF conditions, respectively). Nutrient addition stimulated aerial biomass production even when oil was present; higher aerial biomass in PNC was observed compared to treatments with oil only (PC).

Treatments had also a significant effect on underground biomass production $(p=0.006)$, oiled treatment (PC, PNC) had significantly $(p \leq 0.05)$ lower root biomass $(2.50 \mathrm{~g}, 2.50 \mathrm{~g}$ and $1.89 \mathrm{~g}, 3.09 \mathrm{~g}$, respectively under IF and PF) than PN (4.83 g, $3.97 \mathrm{~g}$ ) treatments (Figure 1). In absence of fertilizer, root biomass in oiled treatment was not significantly different from the non-oiled treatment (P).

Flooding frequency did not have a significant effect on the number of leaves, number of nodes, height, and RGR of A. germinans (Table 2). However, the treatments had a significant effect on number of leaves ( $p=$ $0.0001)$, height $(p=0.006)$ and RGR $(p=0.0001)$. The number of leaves in oiled treatments (PC and PNC) was significantly lower $(26,26$ and 37, 37 respectively under IF and PF) than PN $(66,60)$ treatments but not significantly different from P $(35,37)$ treatments. Plant height was significantly higher in PN $(0.83 \mathrm{~m}, 0.85 \mathrm{~m})$ treatments than PC $(0.62 \mathrm{~m}, 0.0 .63 \mathrm{~m})$ treatments but not different from PNC $(0.67 \mathrm{~m}, 0.73 \mathrm{~m})$ or P $(0.54 \mathrm{~m}, 0.70 \mathrm{~cm})$

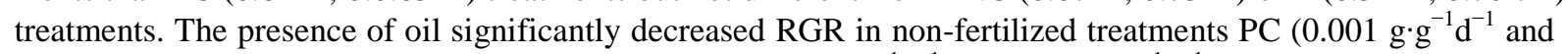
0.001 respectively under IF and PF) compared to $P\left(0.002 \mathrm{~g} \cdot \mathrm{g}^{-1} \mathrm{~d}^{-1}\right.$ and $\left.0.004 \mathrm{~g} \cdot \mathrm{g}^{-1} \mathrm{~d}^{-1}\right)$. A similar decrease was observed in fertilized oil treatments, PNC $\left(0.003 \mathrm{~g} \cdot \mathrm{g}^{-1} \mathrm{~d}^{-1}\right.$ and $\left.0.002 \mathrm{~g} \cdot \mathrm{g}^{-1} \mathrm{~d}^{-1}\right)$ compared with fertilized treatments without oil, PN $\left(0.005 \mathrm{~g} \cdot \mathrm{g}^{-1} \mathrm{~d}^{-1}\right.$ and $\left.0.004 \mathrm{~g} \cdot \mathrm{g}^{-1} \mathrm{~d}^{-1}\right)$.

\subsection{Redox Potential Dynamics}

Average redox potential for each treatment were recorded (Figure 2). In order to investigate if flooding and drainage influenced redox potential, it was measured in all treatments once a week, in the morning, after $14 \mathrm{~h}$ of drainage in IF and evening after $10 \mathrm{~h}$ of flooding. Redox measurements were taken close to the surface $(7 \mathrm{~cm}$ deep) and at the bottom of microcosms (14 $\mathrm{cm}$ deep). It was found that flood frequency had a significant effect on redox potential in the morning and evening at $7 \mathrm{~cm}$ depth ( $p=0.0001$ and $p=0.0001$, respectively) and 14 $\mathrm{cm}(p=0.0001$ and $p=0.0001$, respectively). Treatment and flooding frequency also had a significant effect on

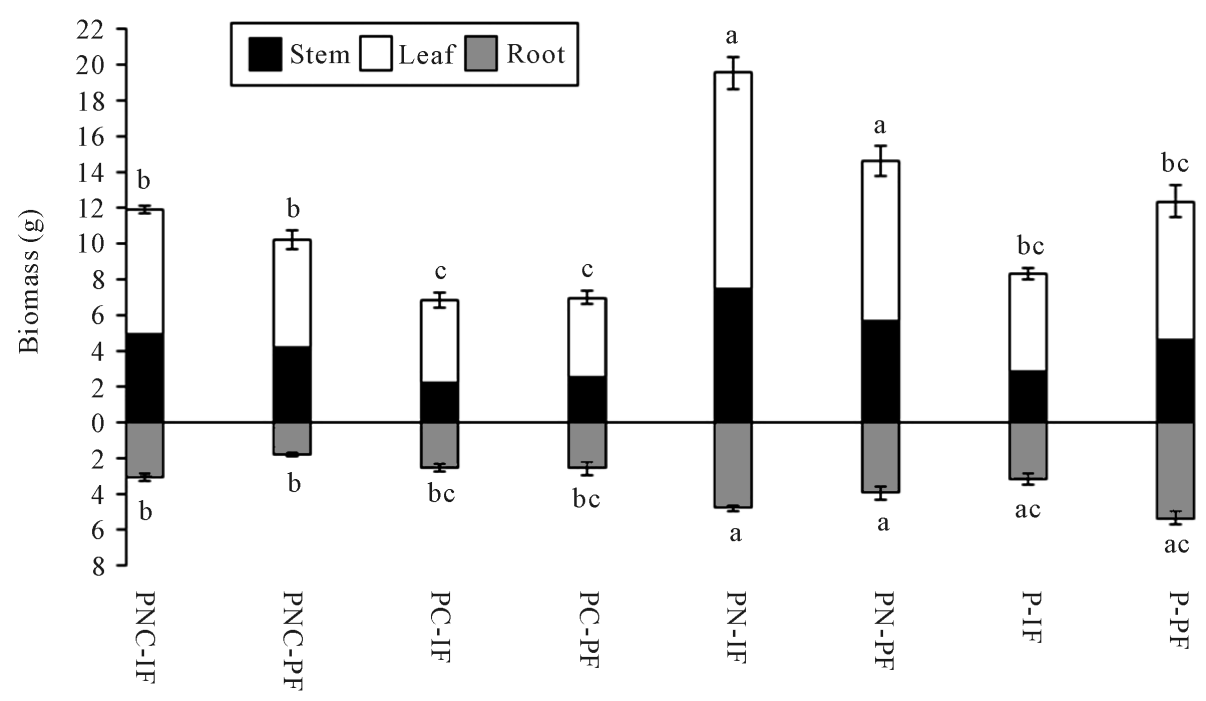

Figure 1. Effect of flooding frequency and nutrient addition on biomass production of $A$. germinans. Values are average \pm standard error, $(n=4)$. Different letters indicate significant differences $(p<0.05)$. IF = Intermittent flooded, $\mathrm{PF}=$ Permanent flooded, $\mathrm{PNC}=$ Planted microcosms with nutrients and crude oil, $\mathrm{PC}=$ Planted microcosm with crude oil, NC = Unplanted microcosms with crude oil. 
Table 2. Effect of flooding frequency, nutrient and oil addition on growth parameters of A. germinans.

\begin{tabular}{ccccccc}
\hline \multirow{2}{*}{$\begin{array}{c}\text { Growth parameter/ } \\
\text { Flood frequency }\end{array}$} & \multicolumn{2}{c}{$\mathrm{P}$} & \multicolumn{2}{c}{ PC } \\
\cline { 2 - 6 } & Intermittent & Permanent & Intermittent & Permanent & Intermittent & Permanent \\
\hline Number of leaves & $36.00 \pm 3.74^{\mathrm{bc}}$ & $37.00 \pm 3.87^{\mathrm{bc}}$ & $26.00 \pm 0.39^{\mathrm{c}}$ & $26.00 \pm 1.26^{\mathrm{c}}$ & $37.00 \pm 0.95^{\mathrm{b}}$ & $37.00 \pm 1.03^{\mathrm{b}}$ \\
Number of branches & $2.00 \pm 0.14^{\mathrm{b}}$ & $3.00 \pm 0.33^{\mathrm{b}}$ & $2.00 \pm 0.10^{\mathrm{b}}$ & $2.00 \pm 0.16^{\mathrm{b}}$ & $3.00 \pm 0.16^{\mathrm{b}}$ & $3.00 \pm 0.24^{\mathrm{b}}$ \\
Stem height $(\mathrm{m})$ & $0.54 \pm 0.02^{\mathrm{b}}$ & $0.70 \pm 0.03^{\mathrm{b}}$ & $0.62 \pm 0.03^{\mathrm{b}}$ & $0.63 \pm 0.07^{\mathrm{b}}$ & $0.68 \pm 0.03^{\mathrm{b}}$ & $0.71 \pm 0.02^{\mathrm{b}}$ \\
Relative growth rate $\left(\mathrm{g} \cdot \mathrm{g}^{-1} \cdot \mathrm{d}^{-1}\right)$ & $0.002 \pm 0.0002^{\mathrm{b}}$ & $0.003 \pm 0.0003^{\mathrm{b}}$ & $0.001 \pm 0.0001^{\mathrm{c}}$ & $0.001 \pm 0.0003^{\mathrm{c}}$ & $0.003 \pm 0.0001^{\mathrm{b}}$ & $0.002 \pm 0.0002^{\mathrm{b}}$ \\
\hline
\end{tabular}

Values are average \pm Standard error $(n=4)$, different letters indicate significant differences between the columns at $5 \%$ significance level $P=P l a n t e d$ microcosms without oil or nutrients, PNC = Planted microcosms with nutrients and crude oil, PC = Planted microcosm with crude oil, NC = Unplanted microcosms with nutrients and crude oil.

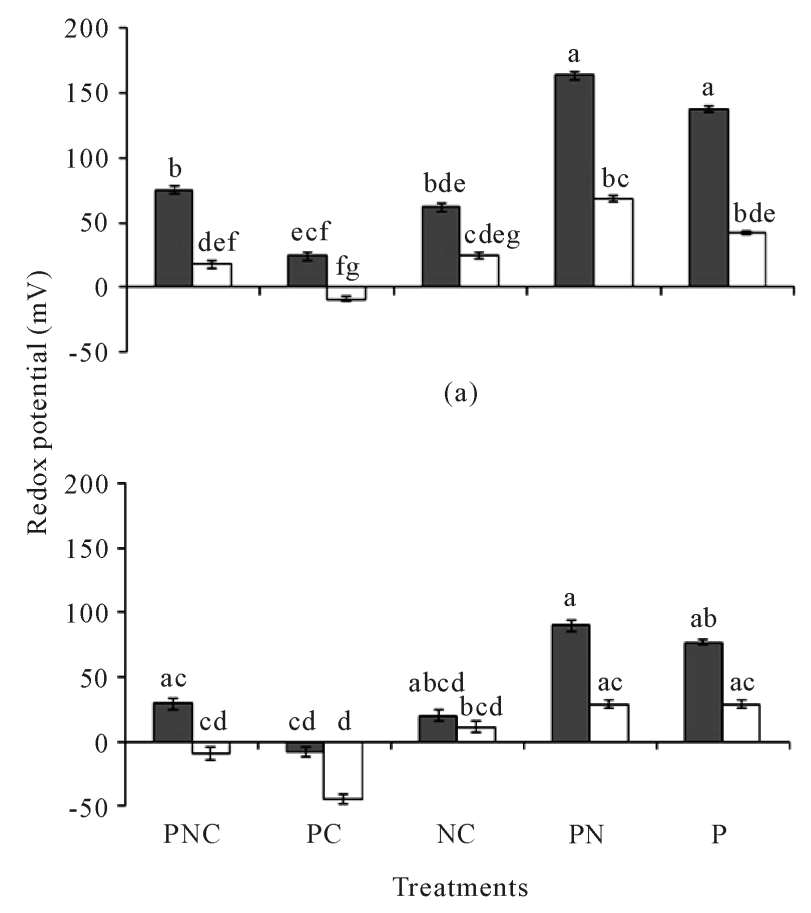

(c)

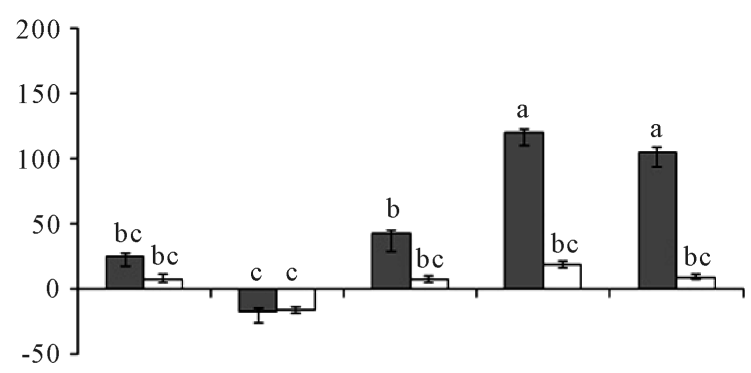

(b)

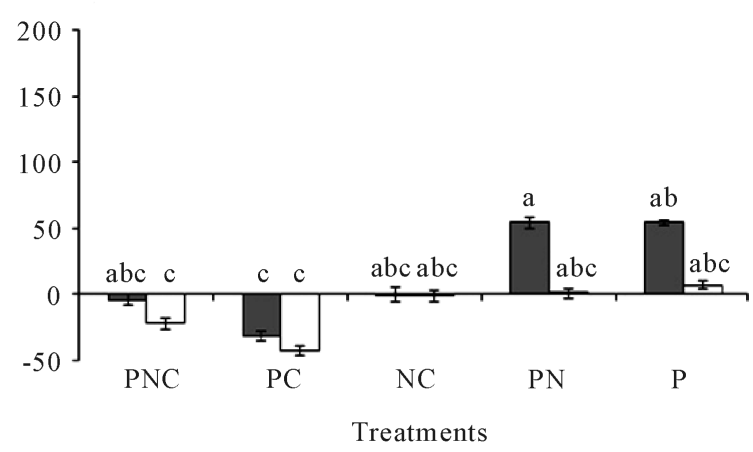

(d)

Intermittently flooded $\square$ Permanently flooded

Figure 2. Average redox potential $(\mathrm{mV})$ in soils of mangrove microcosms, under different treatments, measured at different depths and time, (a) $7 \mathrm{~cm}$ in the morning; (b) $14 \mathrm{~cm}$ in the morning; (c) $7 \mathrm{~cm}$ in the evening; (d) $14 \mathrm{~cm}$ in the evening. $\mathrm{n}=$ $16 \pm$ standard error, $\mathrm{P}=$ plant, $\mathrm{C}=$ Crude oil, $\mathrm{F}=$ fertilizer.

redox potential in the morning and evening at $7 \mathrm{~cm}$ depth $(p=0.0001$ and $p=0.0001$, respectively) and $14 \mathrm{~cm}$ ( $p=0.010$ and $p=0.0001$, respectively).

The average redox potential in PNC was significantly higher $(p=0.001)$ under intermittent flooding $(+90 \mathrm{mV})$ than permanently flooded conditions $(+16 \mathrm{mV})$, but only at $7 \mathrm{~cm}$ deep, in the morning after $14 \mathrm{hr}$. of drainage. For the rest of the oiled treatments (PC and NC), average redox potential was not significantly different under different flooding conditions at either $7 \mathrm{~cm}$ or $14 \mathrm{~cm}$ depth. On the contrary, in treatments without oil (PN, and $\mathrm{P})$, average redox potential in the morning was significantly higher $(p=0.001)$ under intermittently flooded $(+150 \mathrm{mV}$ and $+145 \mathrm{mV}$, respectively) than permanently flooded ( $+55 \mathrm{mV}$ and $+45 \mathrm{mV})$ at $7 \mathrm{~cm}$ depth. At 14 $\mathrm{cm}$ depth, redox values in the morning for PN and P treatments were also significant higher $(p=0.01)$ under IF than under PF conditions (120 mV and $100 \mathrm{mV}$ versus 15 and $30 \mathrm{mV}$ respectively). In the evening, no significant differences were found in redox potential in treatments without oil. 


\subsection{Nutrient Dynamics in Soil}

Under intermittent flooding conditions, phosphate concentrations in the mangrove soils during the study varied from 10 to $80 \mathrm{mg} \cdot \mathrm{kg}^{-1}$, with higher concentrations in the treatments with added nutrient (Figure 3(a)). Consumption of phosphate was more efficient in the treatment without oil, after $120 \mathrm{~d}$. Under permanent flooding conditions phosphate concentration varied from 10 to $120 \mathrm{mg} \cdot \mathrm{kg}^{-1}$. The treatment NC showed the lowest consumption of this ion, indicating that mangrove plants have an important role in uptake of phosphate (Figure 3(d)).

Under intermittent flooding conditions, an increase in nitrate concentration in microcosm soils in all treatments was observed, ranging from 10 to $30 \mathrm{mg} \cdot \mathrm{kg}^{-1}$ soil from day 0 to 80 then after 80 days the nitrate concentration decreased (Figure 3(b)). With permanent flooding condition, the nitrate concentration increased to 10 $18 \mathrm{mg} \cdot \mathrm{kg}^{-1}$, and decreased after 80 days (Figure $3(\mathrm{e})$ ).

In both flooding frequencies, $\mathrm{N}-\mathrm{NH}_{4}$ concentrations in soils without nutrient addition were very low (Figure 3(c)). Under IF, NC treatments showed the higher concentration of ammonia (Figure 3(f)) followed by treatments with plants and nutrients (PNC and PN). Under PF conditions, higher concentrations of $\mathrm{N}_{-} \mathrm{NH}_{4}$ in the soil

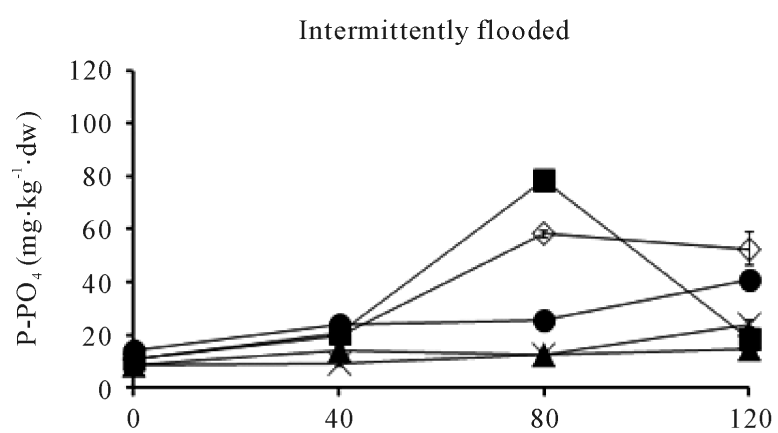

(a)

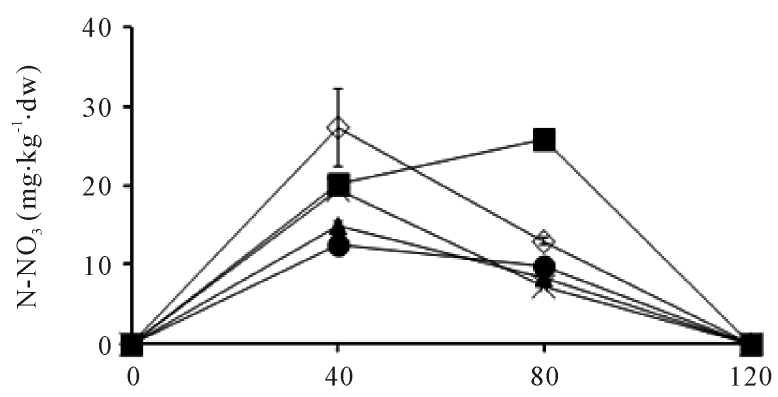

(b)

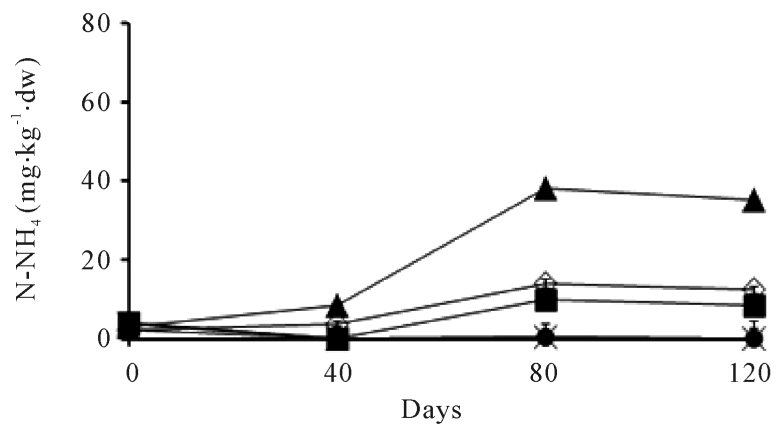

(c)

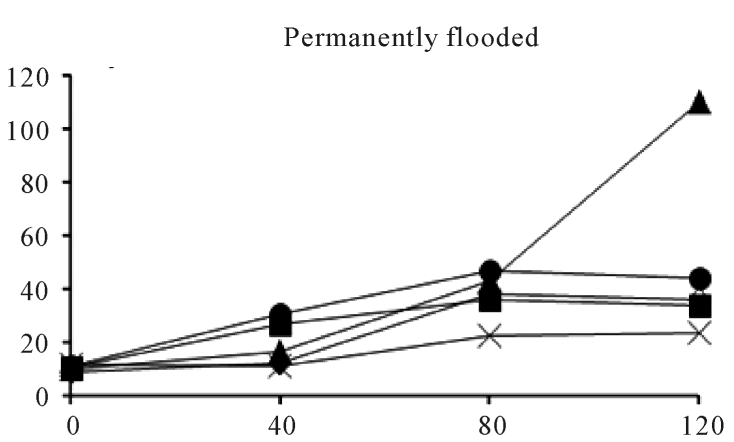

(d)

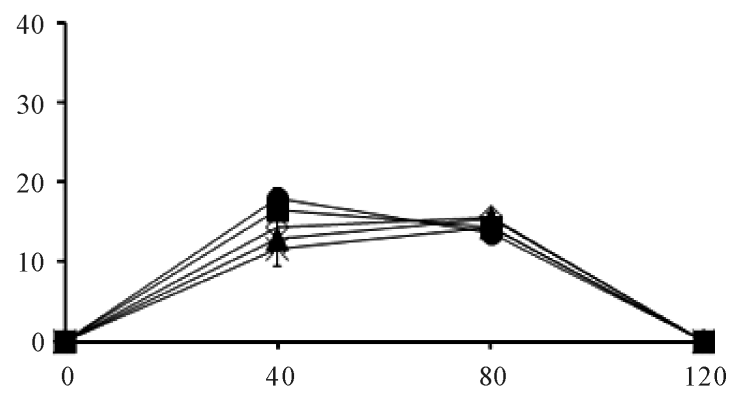

(e)

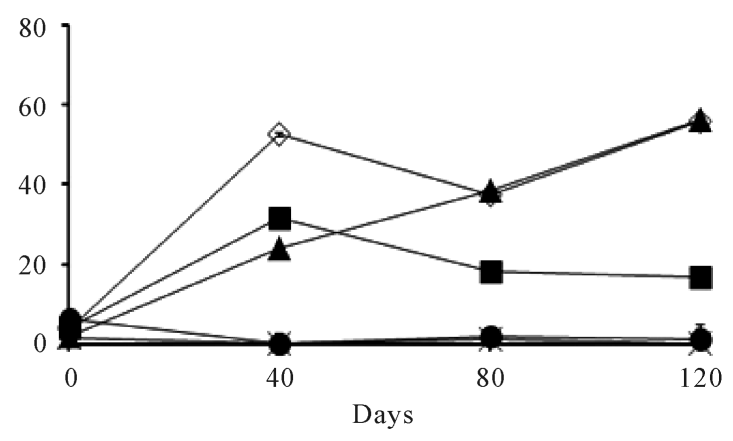

(f)

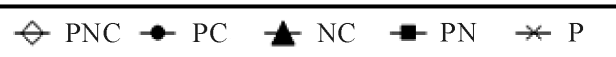

Figure 3. Nutrient dynamics in mangrove soils during the oil removal experiment, (a) $\mathrm{P}_{-} \mathrm{PO}_{4}$ under IF; (b) $\mathrm{N}-\mathrm{NO}_{3}$, under IF; (c) $\mathrm{N}-\mathrm{NH}_{4}$, under IF; (d) $\mathrm{P}-\mathrm{PO}_{4}$, under PF; (e) $\mathrm{N}-\mathrm{NO}_{3}$, under PF; (f) $\mathrm{N}-\mathrm{NH}_{4}$, under PF. 
were observed than under IF conditions. Under PF conditions, PNC and NC treatments showed higher concentrations $\left(50-60 \mathrm{mg} \cdot \mathrm{kg}^{-1}\right.$ ) than under IF conditions. In all treatments, under flooded conditions, a slight decrease in $\mathrm{N}-\mathrm{NH}_{4}$ concentration was observed, indicating the gradual release to the system with pores of the bag.

\subsection{Nutrient Dynamics in Water}

In both flooding frequencies, $\mathrm{P}_{-} \mathrm{PO}_{4}$ concentration in the water did not increase in the treatments without nutrient addition (PC and P). Under IF conditions, concentrations increased up to $1.5 \mathrm{mg} \cdot \mathrm{L}^{-1}$ and after 80 days $\mathrm{P}^{-\mathrm{PO}_{4}}$ decreased. The treatment without plants (NC), showed a small decrease indicating the role of plants in consuming $\mathrm{P}^{-\mathrm{PO}_{4}}$ from the water (Figure 4(a)). Under PF conditions, an increase to $1-1.5 \mathrm{mg} \cdot \mathrm{L}^{-1}$ was observed and there was not decrease for PNC and NC treatments. The decrease was observed only in PN treatment after 100 days (Figure 4(c)).

Nitrate concentration in water increased in fertilized treatments (ranging from 5 to $15 \mathrm{mg} \cdot \mathrm{L}^{-1}$ ), and decreased after 80 days. Treatments without nutrient addition did not show an increase in nitrate concentration in the water (Figure 4(b), Figure 4(d)).

Ammonia nitrogen concentration in the water was below detection limit $\left(5 \mathrm{mg} \cdot \mathrm{L}^{-1}\right)$.

\subsection{Total Petroleum Hydrocarbons Removal in Soils}

Flooding conditions and nutrient addition had a significant effect ( $p=0.045, p=0.047)$ on hydrocarbon removal in mangrove soils (Table 3). Under IF conditions, it was found that $49 \%$ of TPH was removed in the PNC treatment and $54.97 \%$ in NC, whereas in the treatment without nutrient addition (PC), only $15.78 \%$ was removed, after 120 days of treatment. Under PF conditions, degradation of TPH was not significantly different between the treatments. Comparing the two flooding conditions, it was found that under PF conditions, TPH removal in the treatments with nutrients (17\% in PNC treatments and $16 \%$ in NC) was significantly lower than

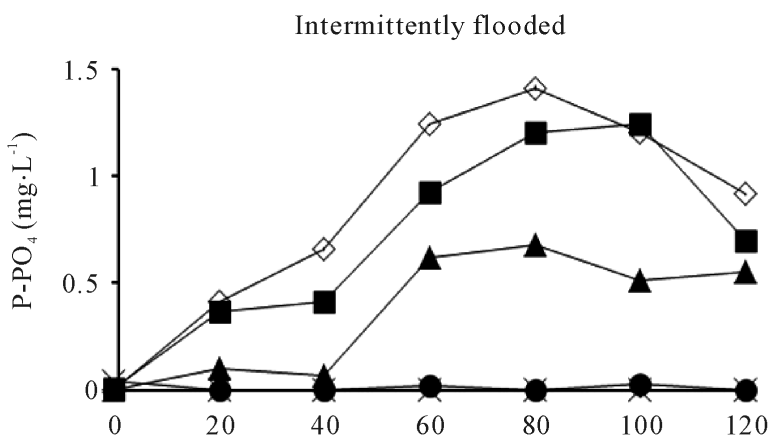

(a)

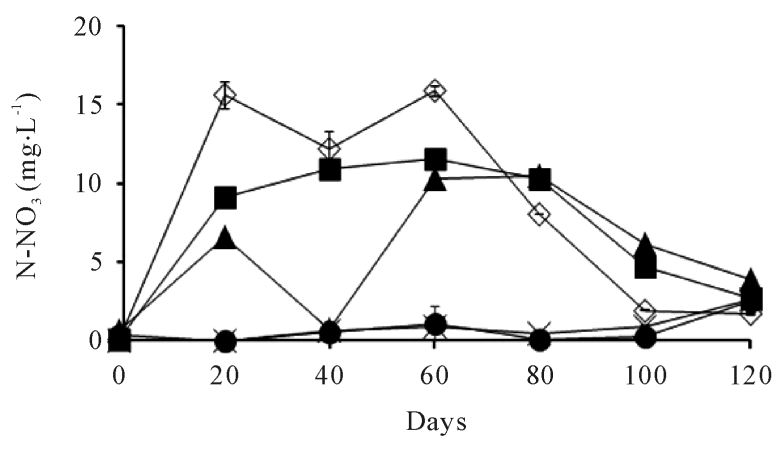

(b)

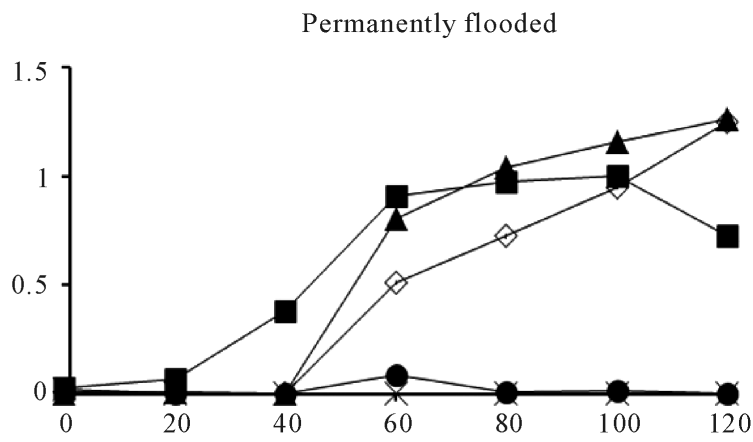

(c)

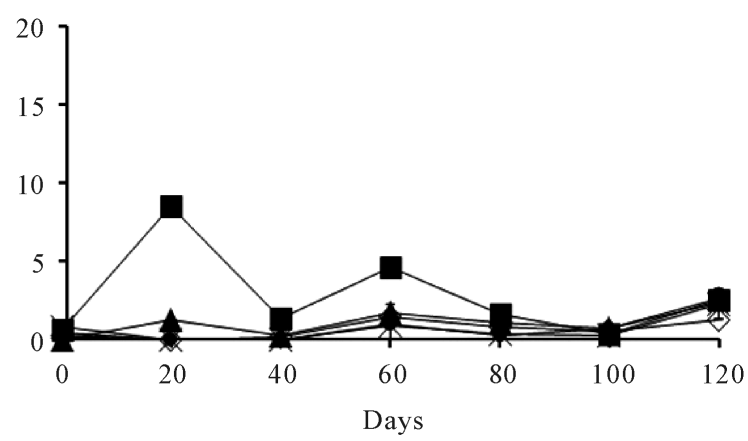

(d)

$$
\diamond \mathrm{PNC} \rightarrow \mathrm{PC} \quad \mathbf{t} \mathrm{NC} \rightarrow \mathrm{PN} \quad \text { * } \mathrm{P}
$$

Figure 4. Nutrient dynamics in water column of mangrove microcosms, during the oil removal experiment, (a) P- $\mathrm{PO}_{4}$, under IF; (b) $\mathrm{N}-\mathrm{NO}_{3}$, under IF; (c) $\mathrm{P}-\mathrm{PO}_{4}$ under PF; (d) $\mathrm{N}-\mathrm{NO}_{3}$ under PF. 
under IF conditions. Such observation indicated that removal of crude oil in these microcosms was strongly limited by oxygen availability.

\subsection{Compartmentalization of THPs in the System}

In order to investigate if the hydrocarbons migrated from soil to water or to the walls of the plastic bins and tank used to flood the system, the amount of hydrocarbon in the different matrices (Table 4) was calculated. For this purpose, the initial total amount of crude oil added to the four microcosm of each treatment and the total amount of water used $(60 \mathrm{~L})$ to flood them were considered. Due to the fact that each treatment had four replicates but they were flooded in the same bin and shared the same water container, a statistical analysis for compartmentalization data was not performed. At day 0 , in the PNC treatments, a low percentage of the initial amount THP in the water $(0.4 \%-3.4 \%)$ was observed. However, after 120 days, the percentage of initial THP in the water increased to $3.9 \%-7.3 \%$. In the PC and NC treatments the percentage of the amount initial concentration of TPH in water ranged from $4.6 \%$ to $23.5 \%$ on day 0 and after 120 days these values decreased to $1 \%-13.2 \%$, indicating removal of TPH from the water. The amount of hydrocarbons adhered to the walls of the hose, bin and containers varied from 3.5\% to 35\% with no clear differences between the treatments. Considering that the hydrocarbons adhered to the walls remains in the systems, the actual percentage of the initial amount of THP removed from the system was calculated. It was found that treatments with nutrients (PNC and NC) under intermittently flooding had the highest amount of TPH removed from the system (27.3\% and $44.9 \%$ respectively).

Table 3. Effect of flooding frequency and nutrient addition on oil removal from mangrove soils, after 120 days.

\begin{tabular}{rccccc}
\hline \multirow{2}{*}{ Treatment } & Inundation & Initial concentration & Final concentration & Removed concentration & Removed \\
\cline { 3 - 5 } & & \multicolumn{2}{c}{$\mathrm{g} \mathrm{oil} \mathrm{Kg}^{-1}$ soil DW. } & & $\%$ \\
\hline \multirow{2}{*}{ PNC } & IF & $3.44 \pm 0.16$ & $1.74 \pm 0.13$ & $1.70 \pm 0.13$ & $49.31 \pm 3.72^{\mathrm{a}}$ \\
& PF & $2.60 \pm 0.54$ & $2.15 \pm 0.10$ & $0.45 \pm 0.10$ & $17.20 \pm 3.70^{\mathrm{b}}$ \\
\multirow{2}{*}{ PC } & IF & $4.87 \pm 0.06$ & $4.10 \pm 0.07$ & $0.77 \pm 0.07$ & $15.78 \pm 1.47^{\mathrm{b}}$ \\
& PF & $4.35 \pm 1.51$ & $4.31 \pm 0.03$ & $0.54 \pm 0.04$ & $12.51 \pm 0.89^{\mathrm{b}}$ \\
& IF & $3.91 \pm 0.45$ & $1.76 \pm 0.15$ & $2.15 \pm 0.15$ & $54.97 \pm 3.95^{\mathrm{a}}$ \\
& PF & $2.07 \pm 0.58$ & $1.73 \pm 0.15$ & $0.34 \pm 0.15$ & $16.63 \pm 7.42^{\mathrm{b}}$ \\
\hline
\end{tabular}

Values are average \pm standard error, $(n=4)$. Different letters indicate significant differences between the rows $(p<0.05)$. IF $=$ Intermittent flooded, $\mathrm{PF}=$ Permanent flooded, PNC = Planted microcosms with nutrients and crude oil, PC = Planted microcosm with crude oil, NC = Unplanted microcosms with nutrients and crude oil.

Table 4. TPHs in different matrixes, at the beginning of the experiment and after 120 days.

\begin{tabular}{|c|c|c|c|c|c|c|c|}
\hline \multirow{2}{*}{ Treatment } & \multicolumn{2}{|c|}{$\begin{array}{c}\text { Day } 0 \text { (\% of initial } \\
\text { amount of TPH) }\end{array}$} & \multicolumn{2}{|c|}{$\begin{array}{l}\text { Day } 120 \text { (\% of initial } \\
\text { amount of TPH) }\end{array}$} & \multicolumn{3}{|c|}{$\begin{array}{l}\% \text { of initial amount of TPH } \\
\text { removed TP removed }\end{array}$} \\
\hline & Water & Soil & Water & Soil & Walls & Volatilization & System \\
\hline PNC-IF & 3.4 & 96.6 & 7.3 & 47.3 & 19.2 & 1.1 & 27.3 \\
\hline PNC-PF & 0.4 & 99.6 & 3.9 & 82.4 & 3.5 & 1.9 & 12.1 \\
\hline PC-IF & 22.5 & 77.5 & 1.5 & 61.8 & 32.5 & 1.1 & 5.3 \\
\hline PC-PF & 23.5 & 76.5 & 1.0 & 64 & 33.2 & 1.6 & 3.4 \\
\hline CN-IF & 4.6 & 95.4 & 2.1 & 41 & 13 & 1.0 & 44.9 \\
\hline CN-PF & 33.3 & 66.7 & 13.2 & 50.1 & 35 & 1.5 & 3.2 \\
\hline
\end{tabular}

IF, intermittently flooded; PF, permanently flooded; PNC, planted microcosms with nutrients and crude oil; PC, planted microcosm with crude oil; NC, unplanted microcosms with nutrients and crude oil. 


\section{Discussion}

\subsection{Effect of Flooding Frequency, Oil and Nutrients on $A_{\text {. }}$ germinans Growth}

In this study, flooding frequency did not affect plant growth. Although a slower growth under permanent flooding than under intermittent flooding was expected because permanent flooding causes stress in some mangrove species, and the genus Aviccenia has been described as flood sensitive [35], such behavior was not observed. This disagreement might be due to a difference between field and greenhouse experiments. Under field conditions, mangrove plants are inundated with a high water column and experience salinity stress (approximately $30 \%$ - 50\%). In these experiments, plants were covered with a small water column $(0.04 \mathrm{~m})$ and salinity concentration was $15 \%$, under permanently flooded conditions. However, such findings are in agreement with results reported in other greenhouse experiments. In a 2-year greenhouse experiment in Lousiana US, Krauss et al., [36] did not find differences in total biomass, height and diameter of Avicennia germinans, Rhizophora mangle and Laguncularia racemosa growth under intermittent and permanently flooded conditions. Also, McKee, [37] did not find differences in aboveground biomass of A. germinans grown under drained and flooded $(0.15 \mathrm{~m})$ conditions in an 8-month greenhouse experiment in Louisiana US.

The effects of oil on mangrove seedlings depend on several factors, such as oil characteristics and concentration, mangrove species and age, and environmental conditions [5] [38]. In this work, it was found that Maya crude oil in concentrations between $3-5 \mathrm{~g} \cdot \mathrm{kg}^{-1}$ of mangrove sediment, decreased the RGR of $A$. germinans by $60 \%$ in non-fertilized treatments, and by $45 \%$ in fertilized treatments. Youssef [10], did not find differences in the RGR of A. marina sprayed with various concentrations [150 and $300 \mu \mathrm{g} \mathrm{plant}^{-1}$ ] of polyaromatic hydrocarbons (PAHs). Proffitt and Devlin, [39] investigated the toxic effect of two concentrations $\left(1.6\right.$ and $16.0 \mathrm{~L} \cdot \mathrm{m}^{-2}$ ) of No. 6 fuel oil on Rhizophora mangle L. seedling propagules and found that sapling survival, total stem growth, numbers of lateral stems produced, numbers of live leaf on plants, and leaf production were significantly reduced by application to the soil of $16.0 \mathrm{~L} \cdot \mathrm{m}^{-2}$ crude oil, but not by the low-crude treatment of $1.6 \mathrm{~L} \cdot \mathrm{m}^{-2}$. The dose used in this study was $0.8 \mathrm{~L} \cdot \mathrm{m}^{-2}$, which indicates high toxicity of the Maya crude oil to A. germinans.

\subsection{Effect of Flooding Frequency and Oil on Redox Potential in Mangrove Microcosm Soils}

The decrease of redox potential in the surface sediments of oiled treatments could be due to the oily film that hydrocarbons formed on the sediment surface, which obstructed the exchange of gases between sediment, water and atmosphere. This phenomenon prevented, even under intermittent conditions, oxygen from the atmosphere from diffusing to the sediment surface; resulting in lo redox potential values. The addition of fertilizer to the planted, oiled microcosms caused better plant growth than non-fertilized plants, which could have contributed to aeration of the sediments by the plants' roots [1] [37]. Aeration of sediments via plant roots would cause higher redox potential, especially when microcosms were drained under intermittently flooded conditions. The decrease of redox potential in sediments after oil addition was also observed in an experimental study of oil bioremediation in salt marsh sediments in Texas US. Redox potential before crude addition ranged from -90 to $+10 \mathrm{mV}$, and after oil pollution ranged from -100 to $-200 \mathrm{mV}$ [40]. In this work, the results regarding lower redox potential in oiled treatments vs. unpolluted sediments also agreed with field observations in Spanish salt marshes, where soil redox potential ranged from -19 to $+114 \mathrm{mV}$ in oil polluted soils, and from +112 to $+164 \mathrm{mV}$ in unpolluted soils [41]. Redox potential values observed in the microcosms of this study without oil $(-150$ to +180 $\mathrm{mV}$ ), are similar to the values reported for drained mangrove microcosms $(+157$ to $+284 \mathrm{mV})$ and for flooded microcosms ( -73 to $+60 \mathrm{mV})$, both planted with A. germinans [37].

\subsection{Nutrient Dynamics in Water and Sediment}

When soils are flooded and conditions become anaerobic, many changes in the availability of phosphorus result. $\mathrm{As}^{3 e^{3+}}$ is reduced to more soluble forms of ferrous $\left(\mathrm{Fe}^{2+}\right)$, phosphorus that is in a specific ferric phosphate is released into solution [1]. This could be the reason why an increase in $\mathrm{P}-\mathrm{PO}_{4}$ concentration was observed in the treatments without nutrient addition, i.e. phosphates could be released from mangrove soils. Release of phosphorous most probably by desorption from the matrix (volcanic gravel) has also been observed in mesocosms planted with Pontederiasagitatta running at a low hydraulic retention time (HRT) of 2.5 days for the treatment of diluted sugarcane stillage [42].

Nitrates are produced in soils by oxidation of ammonia; in wetland soil even under reduced conditions, nitri- 
fication is carried out near the rhizosphere zone [18] [43] [44] and A. germinans in this experiment showed abundant root growth, especially in treatments without oil. Such behavior could explain the increase of nitrate concentration in the sediments without nutrient addition. The higher concentration observed in the IF conditions than in PF treatments, indicated that nitrification was more active in the former type of microcosms.

This study did not detect $\mathrm{N}-\mathrm{NH}_{4}$ concentrations in water (below $5 \mathrm{mg} \cdot \mathrm{L}^{-1}$ ), which could be due to the fact that ammonium has a high adsorptive capacity to organic matter, which is present in the mangrove soils. In a field study, De Laune et al. [46] found that $65 \%$ of the applied $\mathrm{N}-\mathrm{NH}_{4}$ could be recovered in the root and soil fraction after one growing season.

\subsection{Flooding Frequency, Redox Potential, Nutrient Addition and Oil Removal in Mangrove Microcosms}

In wetland soils, oxygen is available only to a limited depth on the top few mm [1]. Oxygen is rapidly consumed, especially under flooded conditions, and hydrocarbon degradation can be inhibited due to limited oxygen availability [45].

The differences in hydrocarbon removal under different flooding conditions and nutrient addition observed in this study indicate the importance of oxygen and nutrient availability in the microbiological process. Under IF, in the fertilized treatments, redox potential ranged from +30 to $+90 \mathrm{mV}$, whereas in treatments without nutrients redox ranged from -10 to $+36 \mathrm{mV}$. Under $P F$ condition in fertilized treatments redox potential ranged from +5 to $+49 \mathrm{mV}$ and in unfertilized treatments redox potential ranged from -25 to $+16 \mathrm{mV}$. Although the differences in redox potential in fertilized treatments are not significantly different between the two flooding regimes, they influenced the hydrocarbon removal, because even when nutrients were available, the hydrocarbon removal under PF was similar to the treatments without nutrients. These results are in agreement with the observation in a lab experiment with sediments of Airplane Lake Louisiana, in which at $\mathrm{pH} 8$ and $+250 \mathrm{mV}, 1.89 \%$ of $\mathrm{C}$ was recovered as $\mathrm{CO}_{2}$ during the degradation of benzo (a) pyrene after 37 days of incubation, whereas at $0 \mathrm{mV}, 0.15 \%$ was recovered and at $-250 \mathrm{mV}$, only $0.01 \%$ recovery [46]. During this study, under IF conditions the soil $\mathrm{pH}$ in the microcosms ranged from 6.8 to 7.9 and from 7.2 to 7.9 under PF. Another study with salt marsh sediments from Barataria basin, Louisiana, reported that at $\mathrm{pH} 6.5 \mathrm{and}+200 \mathrm{mV}, 57.65 \%$ of $\mathrm{C}$ in the form of $\mathrm{CO}_{2}$ was recovered from degradation of naphthalene, whereas at $+50 \mathrm{mV}, 48.70 \%$ was recovered and at $-250 \mathrm{mV}$, only $0.29 \%$ was recovered [27].

In this study, under IF conditions, it was found that nutrient addition increased TPH removal in mangrove sediments, which agreed with studies carried out in salt marsh sediments. In a field study in Nova Scotia salt marshes in Canada, Garcia-Blanco et al. [25], found that $76 \%$ of alkanes and $58 \%$ of aromatic hydrocarbons were degraded in sediments without nutrients, whereas $93 \%$ of alkanes and $74 \%$ of aromatic hydrocarbons were degraded in sediments with nutrients, after 140 days. Jackson and Pardue [23], in a lab experiment with salt marsh sediments found a degradation constant of polyaromatic hydrocarbon of $9.3 \%$ day $^{-1}$ in sediments without nutrients and $32 \%$ day $^{-1}$ in sediments amended with $\mathrm{N}$ and P. In another lab experiment with sediment cores of salt marshes, Shin et al. [45], found that fertilizer amendment improved the decay of some alkanes (undecane, n-tetracosane, n-octadecane, and n-hexatriacontane) after 8 weeks of incubation, while decay of only two PAHs (naphthalene and acenaphthene) was improved. In salt marsh mesocosms, Wright and Weaver, 2004 [47] found after 33 days of experimentation that the $56 \%$ of TPH was degraded in non-fertilized soils and $74 \%$ in fertilized soils.

Few studies have been conducted to examine the effects of biostimulation on hydrocarbon degradation in mangrove soils. Odokuma and Dickson, 2003 [20], in a field study in Nigerian mangroves found that THP degradation in not fertilized treatments was 58\%, while in the treatments with fertilizer; THP degradation was 75\% after 20 weeks.

Yu et al., 2005 [22], in a lab experiment with mangrove sediments slurries found that at the end of 4 weeks, more than $99 \%$ of fluoreno and phenantrene were degraded in treatments without nutrients but only around $30 \%$ of pyrene was degraded. Biostimulation with addition of a mineral salt medium degraded over $97 \%$ of all three PAHs.

\section{Conclusions}

The flooding frequency did not cause any effect on A. germinans growth (leaves, steam diameter, branches, 
height, RGR and biomass). However, the presence of oil decreased the RGR in both fertilized and unfertilized treatments.

In sediments without crude oil, intermittently flooding conditions enhanced higher redox potentials in the top layer than permanently flooding conditions. However, in the microcosms with crude oil, the intermittently flooded conditions enhanced high redox values in the top layers, only in the treatments with plants and nutrients.

Gradual nutrient release was an effective strategy for accelerating removal of crude oil in mangrove soils. However, this strategy was effective when the soils were intermittently flooded, but it was not effective when soils were permanently flooded, this agreed with the hypothesis that intermittent flooding conations enhance TPHs removal. Further studies under field conditions, to verify the feasibility of using this type of fertilization to increase TPHs removal under intermittent flooding conditions should be performed.

\section{Acknowledgements}

This study was funded by the INECOL project \# 20018-100/10339. The authors would like to thank to Gabriel Mercado for his help on mangrove soil collection and Paola Ruiz for her help in laboratory analysis.

\section{References}

[1] Mitsch, W.J. and Gosselink, J.G. (2007) Wetlands. 4th Edition, John Wiley \& Sons, Inc., New York.

[2] Hussain, S.A. and Badola, R. (2008) Valuing Mangrove Ecosystem Services: Linking Nutrient Retention Function of Mangrove Forests to Enhanced Agroecosystem Production. Wetlands Ecology and Management, 16, 441-450. http://dx.doi.org/10.1007/s11273-008-9080-z

[3] Lewis, M., Pryor, R. and Wilking, L. (2011) Fate and Effects of Anthropogenic Chemicals in Mangrove Ecosystems: A Review. Environmental Pollution, 159, 2328-2346. http://dx.doi.org/10.1016/j.envpol.2011.04.027

[4] Sodre, V., Caetano V.S., Rocha R.M., Carmo, F.L., Medici, L.O., Peixoto, M.R., Rosado, A.S. and Reinert, F. (2013) Physiological Aspects of Mangrove (Laguncularia racemosa) Grown in Microcosms with Oil-Degrading Bacteria and Oil Contaminated Sediment. Environmental Pollution, 172, 243-249. http://dx.doi.org/10.1016/j.envpol.2012.09.003

[5] Duke, N.C., Pinzón, Z.S. and Prada, M.C. (1997) Large-Scale Damage to Mangrove Forest Following Two Large Oil Spills in Panama. Biotropica, 29, 2-14. http://dx.doi.org/10.1111/j.1744-7429.1997.tb00001.x

[6] Burns, K.A., Codi, S., Swannell, R.J.P. and Duke, N. (1999) Assessing the Oil Degradation Potential of Endogenous Micro-Organism in Tropical Marine Wetlands. Management Salt Marsh, 3, 67-83. http://dx.doi.org/10.1023/A:1009968101790

[7] Burns, K.A., Codi, S. and Duke, N. (2000) Gladstone, Australia Field Studies: Weathering and Degradation of Hydrocarbons in Oiled Mangrove and Salt Marsh Sediments with and without the Application of an Experimental Bioremediation Protocol. Marine Pollution Bulletin, 41, 392-402. http://dx.doi.org/10.1016/S0025-326X(00)00094-1

[8] Costanza, R., Batker, D., Day, J., Feagin, R.A., Martínez, M.L. and Roman, J. (2010) The Perfect Spill: Solutions for Averting the Next Deepwater Horizon. Solutions, 1, 17-20.

[9] Mendelssohn, I.A., Andersen, G.L., Baltz, D.M., Caffey, R.H., Carman, K.R., Fleeger, J.W., Joye, S.B., Lin, Q., Maltby, E., Overton, E.B. and Rozas, L.P. (2012) Oil Impacts on Coastal Wetlands: Implications for the Mississippi River Delta Ecosystem after the Deepwater Horizon Oil Spill. BioScience, 62, 562-574. http://dx.doi.org/10.1525/bio.2012.62.6.7

[10] Youssef, T. (2002) Physiological Responses of Avicennia marina Seedlings to the Phytotoxic Effects of the WaterSoluble Fraction of Light Arabian Crude Oil. The Environmentalist, 22, 149-159.

[11] López-Portillo, J.A. and Ezcurra, E. (2002) Los manglares de México: Una revisión. Madera y Bosques, 27-51.

[12] Moreno, P., Rojas, J., Zárate, D., Ortiz, M., Lara, A.L. and Saavedra, T. (2002) Diagnóstico de los manglares de Veracruz: Distribución, vínculo con los recursos pesqueros y su problemática. Madera y Bosques, 61-68.

[13] Botello, A.V., Rendón von Osten, J., Gold-Bouchot, G. and Agraz-Hernández, C. (2005) Golfo de México, Contaminación e Impacto Ambiental: Diagnóstico y Tendencias. 2da Edición, Universidad Autónoma de Campeche, Universidad Nacional Autónoma de México, Instituto Nacional de Ecología, Campeche.

[14] Albert, L.A., Bozada-Robles, J., Uribe-Juárez, J., López-Portillo, J., Méndez-Alonzo, R., Antonio-Soto, K., ReyesTrejo, O. and Torres-Nachón, C.J. (2005) Evaluación instantánea de los efectos del derrame de petróleo en el área de Nanchital-Coatzacoalcos, Veracruz. In: Botello, A.V., Rendón, J., Osten, V., Gold-Bouchot, G. and Agraz-Hernández, C., Eds., Golfo de México Contaminación e Impacto Ambiental: Diagnóstico y Tendencias, 2da Edición, Universidad Autónoma de Campeche, Universidad Autónoma de México, Instituto Nacional de Ecología, Campeche, 655-660.

[15] Pezeshki, S.R., Hester, M.W., Linc, Q. and Nyman, J.A. (2000) The Effects of Oil Spill and Clean-Up on Dominant 
US Gulf Coast Marsh Macrophytes: A Review. Environmental Pollution, 108, 129-139. http://dx.doi.org/10.1016/S0269-7491(99)00244-4

[16] Olguín, E.J., Hernández, M.E. and Sánchez-Galván, G. (2007) Contaminación de Manglares por Hidrocarburos y Estrategias de Biorremediación, Fitorremediación y Restauración. Revista Internacional de Contaminación Ambiental, 23, 139-154.

[17] Okoro, C. (2010) Enhance Bioremediation of Hydrocarbon Contaminated Mangrove Swamp in the Nigerian Oil Rich Niger Delta Using Seawater, Microbial Inocula and Amended with Crude Oil Biosurfactants and Micronutrients. Nature and Science, 8, 195-206.

[18] John, R.C. and Okpokwasili, G.C. (2012) Crude Oil Degradation and Plasmid Profile of Nitrifying Bacteria Isolated from Oil Impacted Mangrove Sediment in Niger Delta of Nigeria. Bulletin of Environmental Contamination and Toxicology, 88, 1020-1026. http://dx.doi.org/10.1007/s00128-012-0609-8

[19] Evans, F.F., Rosado, A.S., Sbastian, G.V., Casella, R., Machado, P.L.O.A., Holmstrom, C., Kjelleberg, S., Van Elsas, J.D. and Seldin, L. (2004) Impact of Oil Contamination and Biostimulation on the Diversity of Indigenous Bacterial Communities in Soil Microcosms. FEMS Microbiology Ecology, 49, 295-305. http://dx.doi.org/10.1016/j.femsec.2004.04.007

[20] Odokuma, L.O. and Dickson, A.A. (2003) Bioremediation of a Crude Oil Polluted Tropical Mangrove Environment. Journal of Applied Sciences and Environmental Management, 7, 23-29.

[21] Launen, L.A., Buggs, V.H., Eastep, M.E., Enriquez, R.C., Leonard, J.W., Blaylock, M.J., Huang, J.W. and Häggblom, M.M. (2002) Bioremediation of Polyaromatic Hydrocarbon-Contaminated Sediments in Aerated Bioslurry Reactors. Bioremediation Journal, 6, 125-141. http://dx.doi.org/10.1080/10588330208951209

[22] Yu, K.S., Wong, A.H., Yau, K.W., Wong, Y.S. and Tam, N.F. (2005) Natural Attenuation, Biostimulation and Bioaugmentation on Biodegradation of Polycyclic Aromatic Hydrocarbons (PAHs) in Mangrove Sediments. Marine Pollution Bulletin, 51, 1071-1077. http://dx.doi.org/10.1016/j.marpolbul.2005.06.006

[23] Jackson, W. and Pardue, J. (1999) Potential for Enhancement of Biodegradation of Crude Oil Louisiana Salt Marshes Using Nutrient Amendments. Water, Air, and Soil Pollution, 109, 343-355. http://dx.doi.org/10.1023/A:1005025809014

[24] Coulon, F., Mckew, B.A., Osborn, M.A., Mcgenity, J.T. and Timmis, K.N. (2007) Effects of Temperature and Biostimulation on Oil-Degrading Microbial Communities in Temperate Estuarine Waters. Environmental Microbiology, 9, 177-186. http://dx.doi.org/10.1111/j.1462-2920.2006.01126.x

[25] García-Blanco, S., Venosa, D.A., Suidan, M.T., Lee, K., Cobanli, S. and Haines, J.R. (2007) Biostimulation for the Treatment of an Oil-Contaminated Coastal Salt Marsh. Biodegradation, 18, 1-15. http://dx.doi.org/10.1007/s10532-005-9029-3

[26] Cohen, M.C.L., Lara, R.J., Szlafsztein, C. and Dittmar, T. (2004) Mangrove Inundation and Nutrient Dynamics from GIS Perspective. Wetlands Ecology and Management, 12, 81-86.

[27] Hambrick, G.A., Ronald, D., DeLaune, R.D. and Patrick Jr., W.H. (1980) Effect of Estuarine Sediment pH and Oxidation-Reduction Potential on Microbial Hydrocarbon Degradation. Applied and Environmental Microbiology, 40, 365369.

[28] Reddy, K.R. and Delaune, R. (2004) Biogeochemistry of Wetlands, Science and Applications. CRC Press, Boca Raton.

[29] Sato, G., Fisseha, A., Gebrekiros, S., Karim, H., Negassi, S., Fischer, M., Yemane, E., Teclemariam, J. and Riley, R. (2005) A Novel Approach to Growing Mangroves on the Coastal Mud Flats of Eritrea with the Potential for Relieving Regional Poverty and Hunger. Wetlands, 25, 776-779. http://dx.doi.org/10.1672/0277-5212(2005)025[0776:ANATGM]2.0.CO;2

[30] López-Rosas, H., Moreno-Casasola, P. and Mendelssohn, I. (2005) Effects of an African Grass Invasion on Vegetation, Soil and Interstitial Water Characteristics in a Tropical Freshwater Marsh in La Mancha, Veracruz (Mexico). Journal of Plant Interactions, 1, 187-195. http://dx.doi.org/10.1080/17429140600857693

[31] Hernandez, M.E. and Mitsch, W.J. (2006) Influence of Hydrologic Pulses, Flooding Frequency, and Vegetation on Nitrous Oxide Emissions from Created Riparian Marshes. Wetlands, 26, 862-877. http://dx.doi.org/10.1672/0277-5212(2006)26[862:IOHPFF]2.0.CO;2

[32] Robarge, W.P., Edwards, A. and Johnson, B. (1983) Water and Waste Water Analysis for Nitrate via Nitration of Salicylic Acid. Communications in Soil Science and Plant Analysis, 14, 1207-1215. http://dx.doi.org/10.1080/00103628309367444

[33] Sandell, E. and Onish, H. (1978) Photometric Determination of Traces of Metals. John Wiley and Sons Inc., Hoboken.

[34] Wright, A., Weaver, R. and Webb, R. (1997) Oil Bioremediation in Salt Marsh Mesocosms as Influenced by N and P Fertilization, Flooding, and Season. Water, Air, and Soil Pollution, 95, 179-191. http://dx.doi.org/10.1007/BF02406164 
[35] He, B.Y., Lai, T.H., Fan, H.Q., Wang, W.Q. and Zheng, H.L. (2007) Comparison of Flooding-Tolerance in Four Mangrove Species in a Diurnal Tidal Zone in the Beibu Gulf. Estuarine, Coastal and Shelf Science, 74, $254-262$. http://dx.doi.org/10.1016/j.ecss.2007.04.018

[36] Krauss, K., Doyle, T., Twilley, R., Rivera-Monroy, V. and Sullivan, J.K. (2006) Evaluating the Relative Contributions of Hydroperiod and Soil Fertility on Growth of South Florida Mangroves. Hydrobiologia, 569, 311-324.

[37] Mckee, K.L. (1993) Soil Physicochemical Patterns and Mangrove Species Distribution-Reciprocal Effects. Journal of Ecology, 81, 477-487. http://dx.doi.org/10.2307/2261526

[38] DeLaune, R.D., Pezeshki, S.R., Jugsujinda, A. and Lindau, C.W. (2003) Sensitivity of US Gulf of Mexico Coastal Marsh Vegetation to Crude Oil: Comparison of Greenhouse and Field Responses. Aquatic Ecology, 37, 351-360. http://dx.doi.org/10.1023/B:AECO.0000007047.42636.96

[39] Proffitt, C.E. and Devlin, D.J. (1998) Are There Cumulative Effects in Red Mangroves from Oil Spills during Seedling and Sapling Stage? Ecological Applications, 8, 121-127. http://dx.doi.org/10.1890/1051-0761(1998)008[0121:ATCEIR]2.0.CO;2

[40] LaRiviere, D., Autenrieth, R. and Bonner, J. (2003) Redox Dynamics during Recovery of an Oil-Impacted Estuarine Wetland. Water Research, 37, 3307-3318. http://dx.doi.org/10.1016/S0043-1354(03)00134-9

[41] Andrade, M.L., Covelo, E.F., Vega, F.A. and Marcet, P. (2004) Effect of the Prestige Oil Spill on Salt Marsh Soils on the Coast of Galicia (Northwestern Spain). Journal of Environmental Quality, 33, 2103-2110. http://dx.doi.org/10.2134/jeq2004.2103

[42] Olguín, E.J., Sánchez-Galván, G., González-Portela, E. and López-Vela, M. (2008) Constructed Wetland Mesocosms for the Treatment of Diluted Sugarcane Molasses Stillage from Ethanol Production Using Pontederia sagitatta. Water Research, 42, 3659-3666. http://dx.doi.org/10.1016/j.watres.2008.05.015

[43] Reddy, K.R., Patrick Jr., W.H. and Lindau, C.W. (1989) Nitrification-Denitrification at the Plant Root-Sediment Interface in Wetlands. Limnology and Oceanography, 34, 1004-1013. http://dx.doi.org/10.4319/lo.1989.34.6.1004

[44] DeLaune, R.D., Smith, C.J. and Sarafyan, M.N. (1986) Nitrogen Cycling in a Freshwater Marsh of Panicum hemitomon on the Deltaic Plain of the Mississippi River. Journal of Ecology, 74, 249-256. http://dx.doi.org/10.2307/2260361

[45] Shin, S.W., Pardue, J.H., Jackson, W.A. and Choi, S.J. (2001) Nutrient Enhanced Biodegradation of Crude Oil in Tropical Salt Marshes. Water, Air, and Soil Pollution, 131, 135-152. http://dx.doi.org/10.1023/A:1011955316662

[46] DeLaune, R.D., Gambrell, R.P., Pardue, J.H. and Patrick Jr., W.H. (1990) Fate of Petroleum Hydrocarbons and Toxic Organics in Louisiana Coastal Environments. Estuaries, 13, 72-80. http://dx.doi.org/10.2307/1351434

[47] Wright, A. and Weaver, R. (2004) Fertilization and Bioaugmentation for Oil Biodegradation in Salt Marsh Mesocosms. Water, Air, and Soil Pollution, 156, 229-240. http://dx.doi.org/10.1023/B:WATE.0000036810.81451.83.

\section{Abbreviations}

IF, Intermittently Flooded;

PF, Permanently Flooded;

PNC, Planted Microcosms with Nutrients and Crude Oil;

PC, Planted Microcosm with Crude Oil;

NC, Non-Planted Microcosms with Crude Oil, and Nutrient;

PN, Planted Microcosms with Nutrients;

P, Planted Microcosms without Oil or Fertilizer;

TPHs, Total Petroleum Hydrocarbons;

DW, Dry Weight. 
Scientific Research Publishing (SCIRP) is one of the largest Open Access journal publishers. It is currently publishing more than 200 open access, online, peer-reviewed journals covering a wide range of academic disciplines. SCIRP serves the worldwide academic communities and contributes to the progress and application of science with its publication.

Other selected journals from SCIRP are listed as below. Submit your manuscript to us via either submit@scirp.org or Online Submission Portal.
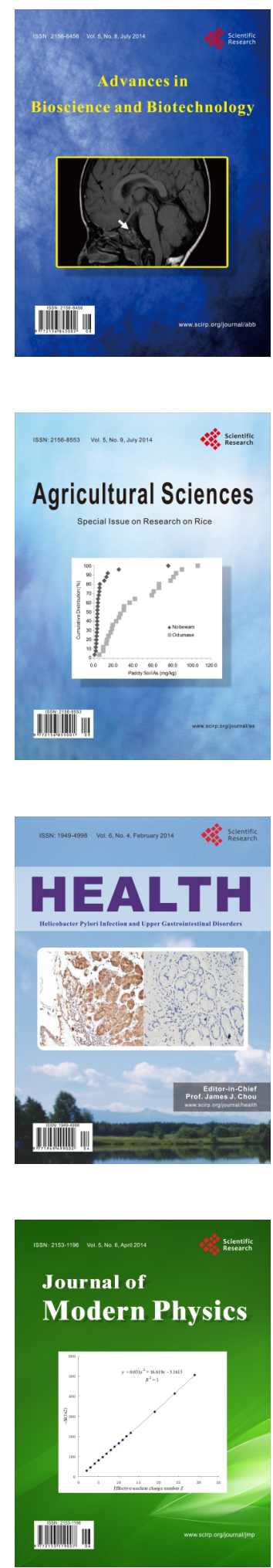
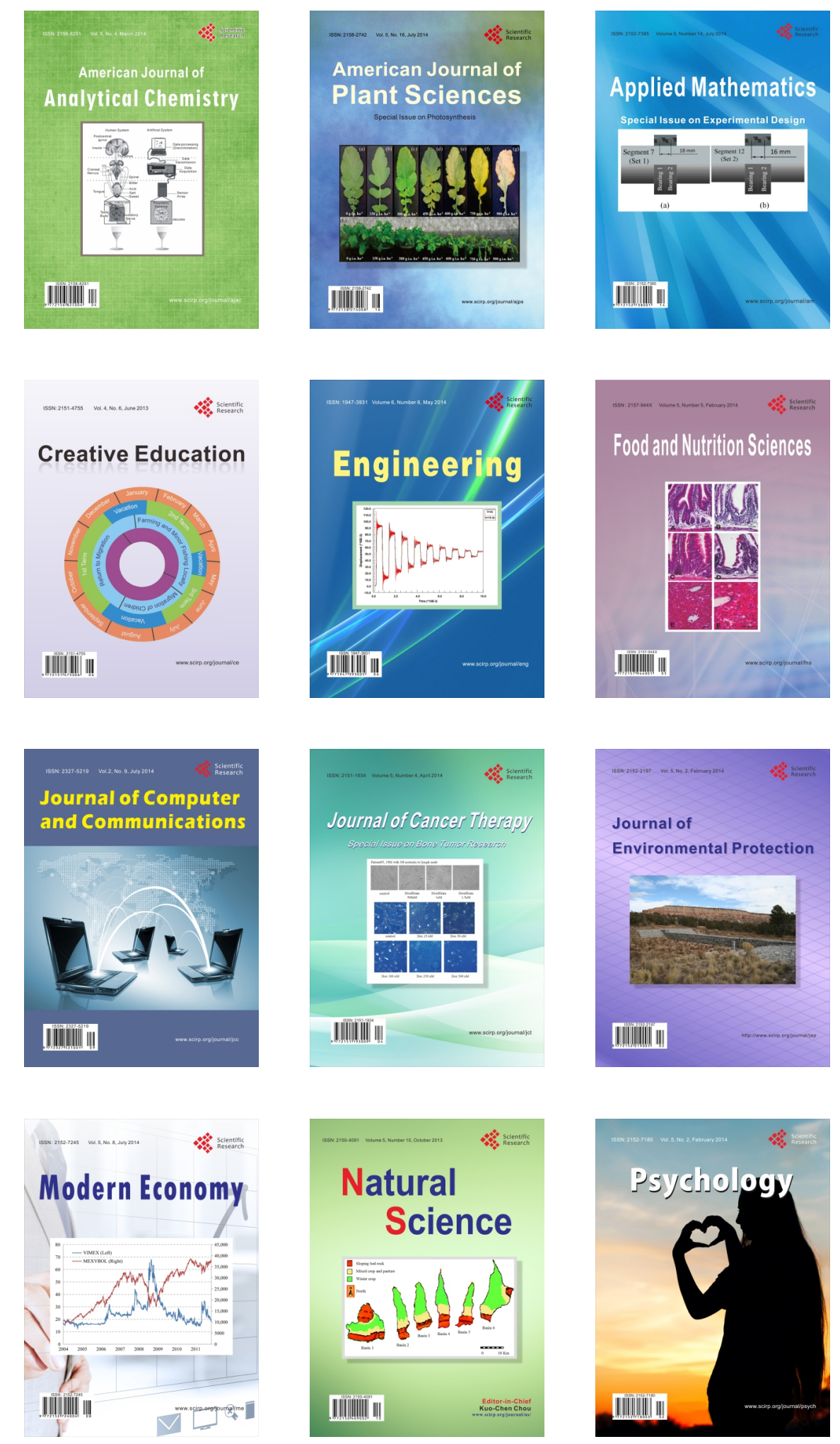